\title{
SLOVAK SYSTEM OF HIGHER EDUCATION IN ITS CONNECTION TO SOCIETY'S TRANSFORMATIONS: TRANSITION FROM MEDIEVAL TIMES TO XXI CENTURY EUROPEAN INTEGRATION
}

\author{
IRYNA MYHOVYCH
}

\begin{abstract}
The article represents an attempt to investigate the development of the national higher education system of Slovak Republic (as part of former Czechoslovakia) starting from the first known data of the medieval times up to the beginning of the XXI century when the period of intense Europeanization and internationalization started. Considerable attention has also been paid to the development of higher education in Slovak Republic after 1989 with the emphasis on relevant legislation, students' enrollment numbers, overall institutional setting. The aim of the paper is to present theoretical review of the Slovak national higher education system development as determined by the processes of socio-political transformations in the country, including the final stage integration to the European Union and European Higher Education Area (EHEA). Theoretical provisions of the paper are supported with relevant statistical data on the number of higher education institutions and the number of students, including the number of those who participate in mobility schemes within EHEA (statistical indicators are gender-sensitive). Attention has also been paid to development of the country's higher education legislation system after the socalled disintegration of Czechoslovakia to Czech and Slovak Republics, which allowed for the establishment and development of private sector within national higher education system. The research is based on the comprehensive analysis of original sources - open-accessed national legal framework for higher education, as well as theoretical and practical research works by Slovak scholars. The topicality of research is determined by the similarity of the Slovak and Ukrainian national systems of higher education at the end of the XX century, which allows to state that consideration of the Slovak context is relevant to the current reforming Ukrainian national higher education system.
\end{abstract}

Keywords: Czechoslovakia, Slovak Republic, system of higher education, education policy, Law on Higher Education, Europeanization, internationalization, private sector of higher education.

\section{INTRODUCTION}

National higher education system of Slovak (and partially correspondingly Czech) Republic (until 1992 Czechoslovakia) were historically formed on the basis of the Humboldtian model of higher education, whose main conceptual principles are the following: 2) academic freedom, which implies freedom of teaching and learning (student chooses disciplines, teachers, and even lesson plan), freedom of scientific inquiry (free search for truth, encouragement of attraction to scientific knowledge); 3) 
university education involves teaching through research work involving teachers and students; 4) active public position of the university - the institution maintains close communication with community, society, is responsible for the formation of public position, ethical substantiation of the benefits of knowledge and education. The four mentioned principles can be considered as highly acute whenever it comes to national higher education systems transition on the way to establishing exceedingly autonomous and research-effective model of operation. In case of Slovak, and at times correspondingly Czech, system of higher education, it has undergone complex process of transformation starting from the point of establishing and up to adjoining the rest of European Union counterparts at the final stage of integration to the European Higher Education Area (EHEA). Taking into consideration on-going reform processes in Ukrainian education sector, as well as commonality of Ukraine and Slovak Republic which derived mostly from the similarity of tasks faced by the postcommunist countries at the beginning of their transformation - specifically in higher education sector the paper in its attempt to present theoretical review of the Slovak national higher education system development as determined by the processes of socio-political transformations in the country, including the final stage integration to the European Union and European Higher Education Area (EHEA) is considered to be as such that might provide insights and correspondingly inputs to the process of Ukrainian higher education sector transformation.

\section{ANALYSIS AND Discussion}

As in case of any national system of higher education, it usually presents a certain challenge to determine its starting point. Going back to the formation of national higher education system of Czechoslovakia (Czech and Slovak Republics), one should say that the first universities of the countries were founded in Prague in 1348 (Université Karlova v Praze - Charles University) and in Bratislava in 1465 (Universitas Istropolitana or Academia Istropolitana). Before the First World War education for countries was a major tool in the fight against ethnic diversity. Instruments of no other branch or aspect of Czechoslovakia's social life made it possible to more effectively overcome differences by removing barriers between Czechs, Slovaks, Hungarians, Ukrainians, Germans, Roma, etc. Eight years of compulsory education in the native language of each ethnic minority did much to increase literacy, especially among Slovaks and Ukrainians. An expanded vocational education programme enhanced the working-class technical skills of the country. The year 1774 is defined as the date of introduction of compulsory education on Czech and Slovak lands in accordance with the Order of Queen Maria Theresa, Archduke of Austria, Queen of Hungary of 1741. A number of reforms, including those in the field of education, marked her ruling. Thus, in accordance with the school reform of 1777 all population of Austrian empire were given the right to educate their children in elementary school in their mother tongue. In Vienna in 1774 a seminary (Barbarium) was opened at St. Barbara's Church to teach Greek Catholic clergy. From 1784 the activity of the University of Lviv was restored, under which the Studium Ruthenium (Russian Institute) was created for the students of Ruthenians, in which the sciences were taught in clerical Slavonic. Thus, the period when the Czech and Slovak lands were part of AustroHungarian Empire was marked by large-scale educational reforms and by formation of a broad network of educational institutions, which led to high literacy of the region's population. The female population, however, was only allowed to study in 1897 [23, p. $34-45]$.

During the First Republic (1918 - 1938) new higher education institutions were established in Czechoslovakia, including, among others, the Veterinary Institute in Brno (Veterinární Institut Brno, 1918); State Higher Trade School in Prague (Státní oysoká škola obchodu v Praze, 1919); Masaryk University in Brno (Masarykova univerzita, 1919); Higher Agricultural School (Vyššia polnohospodárska škola, 1919) and Commenius University (Univerzita Komenského, 1919) in Bratislava, etc. The legal framework for educational policy of the period was the Educational Law No. 226 of 1922, under which mandatory eight-year education was introduced. In addition, it also adopted more than 15 normativelegislative acts on various aspects of higher education, among which there were: 78/1919 "Law on Salaries of Professors of Higher Schools, Universities"; 79/1919 Higher School Teachers Service Act and 
the like. Higher education of the period was traditionally represented by the following educational institutions: Charles University (Univerzita Karlova v Praze), University of Palatsky in Olomouc (Univerzita Palackého v Olomouci), Czech Higher Technical School in Prague (České Vysoké Učení Technické v Praze), Ostrava Technical University (Technická univerzita Ostrava), Law Academy in Prešov (Právnická akadémia v Prešove), National Academy of Economics in Kosice (Národná ekonomická akadémia v Košiciach) [2]. In 1921 - 1922 academic year 24,790 people attended all higher education institutions in the country; 18,961 of those people were citizens of Czechoslovakia. The percentage of women out of this number consisted 9.1 [2]. In fact, Slovaks studied mainly in universities of neighboring Hungary, Austria and the Czech Republic. The characteristic features of the period called the focus of attention of higher education institutions on scientific activity, freedom of teaching, the right to "ensure and the right to recognize professional training".

From 1939 to 1945, during the occupation of Czechoslovakia by Nazi Germany (the country at that time was called the Protectorate of Bohemia and Moravia), higher education institutions ceased their work, as did a number of secondary schools. After the communist upheaval of 1948 the idea of reducing social inequality was the driving force for educational reform in the country where higher education provided the opportunity to study in more prestigious schools, while the children of lower class continued to receive part-time secondary education [10, p. 123 - 139]. At that time the range of educational programmes of Charles University expanded - preparation of medical and chemical fields; Higher education institutions were opened in Plsen and Hradec Kralove; University of Political and Social Studies in Prague was opened (Univerzita politických a sociálních studií v Praze, 1945); the work of the University of Palatsky in Olomouc (Univerzita Palackého v Olomouci, 1946) was restarted; the Academy of Social Sciences (Akademie sociálních věd) in Brno, 1947, and the Institute of Textile Industry in Liberec (Institut textilního prümyslu $v$ Liberci), 1953, were opened. The legal framework for the functioning of Czechoslovak higher education system of the period was defined by the Law No. 58/1950 on Higher Education, which outlined the following objectives of national higher education: the focus on improving the living conditions and cultural standards of the nation, the development of science and technology to build socialism in the country; education of professionally and politically highly qualified personnel; ensuring access to all levels of education; dissemination of achievements of science and art. The law also normalized the organizational and managerial (governing) bodies of higher education institutions - the rector, vice-rectors, council and general assembly, etc. In accordance with the provisions of the Law theological faculties were removed from all higher education institutions; instead, it became compulsory for all educational institutions to open a department of Marxism-Leninism [28]. According to Historical Journal of Czechoslovak Socialist Republic [5], there were three universities operating in the current Slovak Republic in 1945 - 1946 academic year, with 12 faculties, 8,672 Slovak students enrolled, of whom 18.6 percent were women. Therefore, among the peculiarities of the period the following are to be mentioned: strengthening state regulation of higher education system, in particular by adopting the Law No. 58/1950 "On Higher Education"; expanding the network of higher education institutions; increasing the number of enrolled to higher education institutions; ideologizing the content of educational process.

From early 1960s until 1968 (during the so-called Prague Spring), political situation in the country became partially stabilized, class inequalities in the attainment of secondary and tertiary education decreased, and the process of social equalization and discrimination in obtaining educational services by citizens took place. The process, however, ended when the Warsaw Pact troops occupied the country in 1968, and the political and social conditions of life became tighter, there was a general increase in unemployment across the country due to the lack of jobs, overall depression and structural changes in the country. This situation caused the increase in social uncertainty, and from the point of view of qualification training of workers - their low professional skills. Consequently, in 1970s and 1980s there was an unprecedented slowdown in the development of education (especially higher education). Although, given the statistics, the number of students of higher education institutions of Czechoslovakia in the postwar years still increased - from about 50,000 people in the 1950s up to 110 120,000 people in the early 1990 s ( 94,723 of whom were full-time students, $44.8 \%$ of them were women), 
including the breakup of Czech and Slovak common state (in 1960 - 1961 academic year the number of universities increased to 16 (with 33 faculties), which is the highest figure during the whole period since 1945 to 1990) [4]. In 1980 the Government of Czechoslovakia adopted the new Law on Higher Education, according to which all higher education institutions were subordinate to the relevant Ministry; it fully controlled their activities, including the appointment of academic officials. However, already in 1989 the updated Law on Higher Education abolished the Institute of Marxism-Leninism, renewed the procedure for electing the leadership of universities and faculties with the active participation of students, introduced the accreditation procedure, etc. Thus, Czechoslovakia's higher education naturally underwent a transformation from the phase of its establishing to the development of Austro-Hungarian Empire and to the changes brought about by the $20^{\text {th }}$ century - it also had an elitist character and was not popular with the majority of the country's population; the widespread attitude of Czech population to the intelligentsia was more negative than in any other state of the Soviet bloc. This fact was noted by members of the Soviet delegation who visited Czechoslovakia in 1953; according to them, "In no other country did they encounter such a 'sectarian' attitude to intelligentsia" [7, p. 3].

Despite political and social imbalance Czechoslovakia from the medieval times up to the beginning of the $19^{\text {th }}$ century entered the era of communism with a high level of education of its population. The totalitarian regime, like in other countries, changed the educational paradigm of Czechoslovakia in accordance with the principles of ideologization, politicization, centralization of national education systems with unified educational programs, plans, and textbooks, evening and vocational education for adults. At the same time, it should be noted that the national system of higher education of Czechoslovakia differed significantly from, for example, the Polish degree of institutional relationship with foreign universities from the period 1950 - 1989. The Czechoslovak system underwent not only severe restrictions on contacts with Western scholars, but also tighter and more formal control as a result of change in the vector of development towards a totalitarian model of functioning. Following Hendrichová, we claim that Czechoslovak universities at that time were more closed to the outside world than Hungarian or Polish ones [6, p. 105 - 118] - any foreign publications and official academic contacts were prohibited. In Czechoslovakia of the mentioned period, there were 23 higher education institutions operating in accordance with unified principle of organization of educational process and institutional structure of management.

The process of restructuring of national higher education system of Slovak Republic started in 1990 by the adoption by the government at that time of the common state of Czechs and Slovaks of the Law on Higher Education. Education analysts identify the following key systemic features of the Law: quantitative parameter for the development of the country's national higher education system, an indicator of which was an increase in the number of higher education institutions of all types and forms of ownership; elimination of centralized management of higher education by the state; formation of a new model of the university (or its own return to the old model) as autonomous in its activities and realization of the rights and freedoms of an educational institution, which has the freedom to teach and carry out scientific research; diversification of the higher education system [21, p. 16 -18]. We share the opinion of a number of Slovak scholars (E. Benova, M. Fabus, 2012; D. Malova, E. Lastin, 2000; B. Kosova, S. Porubski, 2007; P. Mederli, 2013; A. Kaplanova, 2000, R. Kralikova, 2015, O. Kananykina, 2013, etc.), which take into account the need for such steps by the government, since in the early 1990s the level of public distrust and frustration in the model of centralized management of higher education as a marker of loyalty to the totalitarian political regime was high [1].

The establishment of an independent state of Slovaks in 1993 gave a new impetus to the process of reforming of Slovak higher education system. The period of 1993 - 1998 was related to the nominal proclamation of European integration course on the development of national higher education system and the real deepening of authoritarian nationalist tendencies both in the country and in the field of higher education. The political context naturally reflected on the education system, whose development goals ranged between openness (Europeanization, Internationalization) and closedness (nationalization). Systemic changes in education during this period did not occur, only minimal changes were made at 
the level of formal organization and administrative management of the educational process. In contrast to the dominant stabilizing tendencies in the development of higher education, there were attempts at innovations, which were manifested, first of all, at the micro-level of educational process - activities of educational NGOs, initiative groups and pedagogical associations, which developed educational, didactic materials of different teaching alternatives. The absence of systemic changes during this period, however, did not prevent the increase in the number of higher education institutions and the creation of new faculties. As in Czech Republic, universities were opened in Slovakia in all regions, their highest concentration was in the capital of the state, Bratislava - 5 higher education institutions (Ekonomická univerzita v Bratislave), Commenius University (Univerzita Komenského), Slovak Technical University (Slovenská technická univerzita), Academy of Musical Arts (Vysoká škola múzických umení v Bratislave) and Academy of Fine Arts (Vysoká škola výtvarných umení v Bratislave). There were three universities in the regions of Košice - Technical Univesity (Technická univerzita $v$ Košiciach), University of Veterinary Medicine and Pharmacy (Universita veterinárskeho lekárstva a farmácie), Pavel Jozef Šafarík University (Univerzita Pavla Jozefa Šafárika); and Banska Bystrica (Matej Bel University (Univerzita Mateja Bela $v$ Banskej Bystrici), Academy of Arts (Akadémia umení v Banskej Bystrici), Zvolen Technical University (Technická univerzita vo Zvolene)). The first private university in the country was the Trencin College of Management (1999). Other private higher education institutions were opened in 2003. In 2008 ten private universities provided educational services in Slovak Republic (Bratislavská medzinárodná škola liberálnych štúdií, 2006; Paneurópska vysoká škola (Bratislavská vysoká škola práva), 2004; Vysoká škola ekonómie a manažmentu verejnej správy, 2004; Vysoká škola zdravotníctva a sociálnej práce sv. Alžbety, 2003; Vysoká škola bezpečnostného manažérstva, 2006; Vysoká škola medzinárodného podnikania ISM Slovakia, 2005; Vysoká škola manažmentu v Trenčine, 1999; Dubnický technologický inštitút, 2006; Stredoeurópska vysoká škola v Skalici, 2005; Vysoká škola v Sládkovičove, 2005), and students had the opportunity to study at 14 faculties of different specialization. However, as in case of Poland and Czech Republic, the functioning of private higher education institutions leaves open the question of the quality of teaching in them, as not every region or city in which such institutions are located has properly qualified teaching staff.

Among the determining factors for process of opening of new higher education institutions on the territory of the country there was the fact that in 1996 the profile Ministry of the country prepared and presented to the public the Strategic Plan for Universities, which essentially represented a strategy of decentralization of national higher education system, its regionalization, according to which universities had to operate in all eight administrative centers of the country after the administrativeterritorial reform. In 1998, the new government proclaimed the need for a profound reform of higher education system to complete those changes that had been initiated in previous years - in a government program statement, education development was prioritized, and course was taken to create a coherent concept for the long-term development of education [16, p. 28]. A government commission was created in May 1999 to develop the Concept of Development of Education in Slovak Republic for the Next fifteen - twenty years (Milénium Project) [8].

In June 1999 the officials of Slovak Republic signed the Bologna Declaration, and the country joined the European Higher Education Area [19]. The strategy for the implementation of the principles of Bologna Declaration was defined in the following 2000 in Government Programming Document The Concept of Higher Education Development in Slovakia in the 21s Century [24]. The Government's 2002 Program Declaration, which stated the state of higher education at that time, outlined the guidelines and mechanisms for change, confirmed the need to move towards the harmonization of Slovak higher education system with the European goals of Bologna Process, European integration and internationalization. These documents, as well as the provisions of the UNESCO Declaration on Higher Education (1998) and the Czech Law on Higher Education [9, p. 20], were the basis for the new Law on Higher Education adopted in 2002 and the Government's Resolution on the Credit System of Education adopted in the same year [22, p. 6250 - 6264]. According to the new law the autonomy of higher education institutions was significantly expanded, while the state's influence on their institutional functioning was reduced. The law [25, p. 1462 - 1514] settled a wide range of issues regarding the legal 
status of universities, their funding and management, educational programs and specialties, accreditation, status of teachers and students, their social support, etc. The Law also significantly strengthened the financial autonomy of universities. A system of financial diversification was introduced, which allowed universities to raise funds from many sources through their own activities. However, more importantly, the involvement of such highly flexible financial mechanisms made it possible for external stakeholders to become involved in the management of higher education. The Law also regulated the structural division of national higher education system distinguishing three types of education institutions: public (verejné), state (štátne) and private (súkromné), and outlined the mechanism of activity of foreign higher education institutions on the territory of Slovak Republic [26, p. 1508 - 1510]. The system of two main education cycles was established: undergraduate and postgraduate. Higher education institutions had education programs and academic degrees of three levels: 1) Bachelor; 2) Master (engineering, doctoral); 3) Doctoral Studies [27, p. 1483 - 1486].

During 2002 - 2006 in accordance with the normative documents, the European Credit Transfer System was introduced, and the system of educational specialties was restructured in terms of their number and content. In 2002 due to the need for consolidation of higher education system and centralization of university management, the autonomy of faculties (legal entity status) was abolished, which occurred at the same time as the financial autonomy of universities and the transfer of ownership of real estate. Under the new law public higher education institutions were granted ownership of property in 2003 and became self-governing organizations, but had a supervisory authority appointed externally by the relevant Ministry. Thus, the Ministry created a mechanism and body of external public administration, which some researchers consider to be a body of indirect influence of the state on the financial issues of universities, in particular the sale / purchase of higher education institutions, a mechanism that reduced the risk of corruption by administration of universities [18, p. 36].

Over the next few years the tendency to increase the autonomy of higher education institutions continued. Stakeholder engagement and the role of national public advisory bodies in the governance and functioning of higher education system were strengthened on stakeholder engagement issues, and especially on the development of new educational programs in line with the principles of European integration and internationalization.

The current law was amended in 2003 - 2004 to align national higher education legislation with EU law, in particular to adapt the content of higher education to European Union directives [20]. Important was the accession of Slovak Republic to the European Union in 2004, which gave impetus to the reform of national higher education system in the context of implementation of the government's political plans and commitments, as well as the provisions enshrined in the international agreements on the development of Bologna Process (Prague Communiqué, Berne communique, etc.). During the preparatory period the public administration system, including higher education, was subject to reform and adaptation (Laws 209/2002, 401/2002, 442/2003, 465/2003, 528/2003) [1; 9; 11, p. 100 - 104]. The changes were aimed at eliminating technical flaws and making the necessary decisions in the run-up to accession to the European Union. A number of changes was subsequently made to the law (Laws 365/2004, 455/2004, 523/2004, 578/2004, 5/2005, 332/2005, 363/2007, 175/2008, 462/2008, 469/2009). The new legislation introduced the following fundamental provisions $[1 ; 15]$ :

- introduction of university and non-university (specialized) higher education sectors, as well as the concept of a research institution;

- acceptance of foreign universities, which receive a state license to operate in Slovak Republic in the status of private educational institutions;

- influence on the work of academic self-government bodies;

- establishing private universities sector after obtaining a state permit (license) - since 1999;

- changes in the mechanism of financing of higher education;

- provision of educational services for students for free; development of student register and register of employers; 
- changes in accreditation: educational process in higher education institutions can only take place under accredited educational programs; accreditation of institutions takes place without taking into account their national classification;

- support for student mobility; students obtained the right to change educational program during their studies;

- new additional training fees were introduced.

Since September 2005 newly structured according to Bologna provisions educational programs of three-year Bachelor and two-year Master programs started to be used in the educational process. In 2006 new government declared the need for a new higher education strategy and further changes in higher education, but its political vision was not clear at that time. For the next four years the strategy was not elaborated [17]. Despite the practice of widespread two-level decentralization of higher education management, centralization of university management remained in the country at that time [9]. In 2010 the next government made substantial changes to the law in line with the reform, but they were never approved. In 2012 early parliamentary elections were held and a new government was formed. In 2013, comprehensive assessment of the development of higher education system was made and a new strategy for education system as a whole (including higher education) developed. This strategy was presented to the public for broad public discussion, and with a large number of proposals submitted to the Government; some provisions of it were included in the National Reform Program.

\section{CONCLUSIONS}

The regulatory framework of Slovak national higher education system has continuously been updated in order to improve various aspects of the activities of national higher education institutions and the functioning of higher education in general. The obvious consequence of the reform was the acceleration of internationalization of higher education system. Internationalization has been viewed as a reaction to the global transformation processes that national systems of higher education are currently undergoing, as well as a possibility for national higher education systems to ensure complex educational, administrative, research, and cultural integration into European Higher Education Area [13; 14]. In case of Slovak Republic this process contributed to the expansion of multilateral international cooperation of Slovak universities, their competitiveness and openness, the improvement of the quality of teaching and research. Slovak Republic has joined the European Union programs in the field of education, research, and training (SOCRATES, Leonardo da Vinci (1995 - 1999), SOCRATES II, Leonardo da Vinci II (2000 - 2006), ERASMUS, Jean Monnet, TEMPUS). Opportunities for student mobility have been offered by multilateral agreements signed up by the relevant Ministry. As a result, Slovak youth were given opportunities to study at European universities. Thus, according to the Eurostat European Statistical System, the dynamics of mobility of Slovak students is constantly increasing: in $2001-8,300$ people, $2002-10,300$ people, $2003-13,500$ people, $2004-14,600$ people, 2005 - 16,900 people, $2006-22,300$ people, $2007-24,600$ people, $2008-27,000$ people, $2009-29,400$ people, 2010 - 32,300 people, 2011 - 33,500 people, 2012 - 35,400 people - citizens of the Slovak Republic studied outside their country [3]. The obvious advantage of joining of Slovak Republic, as well as of Poland and the Czech Republic, to European Higher Education Area was the intensification of international contacts between students, teachers, institutions and, as a result, the deepening of the internationalization of higher education.

The restructuring process of higher education system of Slovak Republic, as an interim result, allows to speak about the functioning of 36 higher education institutions in the country as of the beginning of 2017, 20 of which were public (state financed from the state budget), 13 - private, 3 state specialized (military, police, medical institutions); in addition there were five foreign universities (4 Czech and 1 German university). As of the 2012 - 2013 academic year 205,000 students studied at state universities: public $-165,000$ of people, private $-36,000$ of people, state specialized $-4,000$ of people. The largest institution of higher education in the country is Comenius University in Bratislava with 28,000 students enrolled. Despite the stages of reform higher education system of Slovak Republic 
retained 2 scientific degrees - PhD (until 1997 - Kandidat vied (CSc) and Doctor of Sciences (Doktor vied, DrSc) [12].

Despite the existence of problematic areas, there have been significant changes in higher education system in Slovak Republic focused on updating all its structures and legal framework, modernizing the content and methods of training specialists in the context of joining European Higher Education Area. The intensity and effectiveness of reform at different stages of state development varied: in $1990-1992$ basic changes occurred in the process of post-socialist modernization and democratization of higher education system. This period was characterized by democratization of the system of management of higher education institutions, dismantling of previous ideological educational structures, delineation of new guidelines for the development of higher education. In spite of the fact that in this period educational policy of the state, the pro-reformist sentiments on the part of teachers' associations and public opinion were united in understanding the necessity of transformation, no effective mechanism for implementation of reforms was elaborated.

In the phase of Europeanization transition there were partial changes at the level of educational structures; and it is only in the context of the implementation of the European integration course that we can talk about systemic changes in the country's higher education. The subsequent years suggest the following distinctive features of the restructuring of the national higher education system:

1) decentralization both territorially and politically, as well as massification and regionalization at the beginning of the reforms contributed to the creation of strong regional universities, which had positive impact on democratization and economic and social development of the whole country;

2) creation of a model of autonomy based on the principle of independence of universities from the relevant Ministry and faculties from the university and granting broad rights and freedoms to the basic level in higher education system - the faculty; value transformations and Europeanization of the academic environment itself, which became a good precondition for changes in university management;

3) introduction of university autonomy, including financial and property rights to universities, contributed to financial stabilization of higher education;

4) under broad rights and freedoms, the state (government and ministry) by law retained the right in democratic forms to participate in the management of higher education institutions through the created system of influences and counterbalances (which makes it impossible to monopolize the management of academic oligarchy).

Thus, the analysis of the main stages and features of the development of higher education system of Slovak Republic showed both the complexity of its transformation path and the possibility of incorporating Slovak experience in Ukrainian system of higher education which is currently undergoing complex process of reforming, modernizing, and adapting to the requirements of the European Union. For Ukraine this experience can also be considered as an example of good governance practices, which should be analyzed to reflect the most effective solutions for higher education management decisions in national education policy.

\section{REFERENCES}

[1] Benova E., Fabus M. Systemic processes of democratization of higher education in Slovakia. Scientific Papers of the Bukovinian University, 8 (2012). Available at: https://journal.bukuniver.edu.ua/ media/issue_articles/12_3.pdf

[2] Český statistický úřad. (2010). Available at: http://www.czso.cz/csu/2010edicniplan.nsf/t/ FF001EC365/\$File (in Czech) 
[3] European Statistical System EUROSTAT. (2020). Available at: https://ec.europa.eu/eurostat/documents/10186/756730/ESS-Vision-2020.pdf/8d97506b-b802-439e-9ea4$303 \mathrm{e} 905 \mathrm{f} 4255$

[4] Národní archiv. Federální statistický úřad. Statistická ročenka České a Slovenské federativní republiky 1992. Available at: http://www.badatelna.eu/fond/568/ (in Slovak)

[5] Národní archiv. Federální statistický úřad. Historická ročenka České a Slovenské federativní republiky 1985. Available at: http://www.badatelna.eu/instituce/Narodni_archiv/fondy (in Slovak)

[6] Hendrichová J. Decision-Making in Czech Higher Education after November 1989. In: Higher Education Reform Processes in Central and Eastern Europe. Peter Lang, Frankfurt, 1995, 105-118.

[7] Kalinová L. Příspe`vek k historickému výzkumu mobility československých de`lníku po roce 1948. Praha: Ústav marxismu-leninismu pro vysoké školy, Přehled 3/1967. (in Czech)

[8] Koncepcia rozvoja výchovy a vzdelávania v Slovenskej republike na najbližších 15 - 20 rokov (projekt MILÉNIUM). Available at: http://www.noveskolstvo.sk/upload/pdf/MILENIUM.pdf (in Slovak)

[9] Kralikova R. Different faces of one higher education governance model. How do the domestic actors translate supranational trends within European context? Available at: http://ecpr.eu/filestore/paperproposal/b4b68907-7269-4fe1-a411-f4bf4b7555c0.pdf

[10] Kreidl M. Politics and secondary school tracking in socialist Czechoslovakia, 1948-1989. European Sociological Review, 20 (2) (2004), 123-139. Available at: www.jstor.org/stable/3559649

[11] Malova D. Higher Education in Slovakia: A Complicated Restoration of Liberal Rules. East European Constitution Review, 9 (3) (2000), 100-104.

[12] Ministry of Education of the Slovak Republic. Available at: https://www.minedu.sk/about-the-ministry (in Slovak)

[13] Myhovych I. Internationalization as the factor of influence as to the transformation of systems of higher education in the countries of Eastern Europe. Bulletin of Luhansk Taras Shevchenko National University. Pedagogical Sciences, 8 (313) (2017).

[14] Myhovych I. Internationalization Process as a Way to Ensure Quality of Higher Education in Ukraine. Education and Pedagogical Sciences, 1 (168) (2018).

[15] National Council of the Slovak Republic. Law No.131 of 21 February 2002 on Higher Education and on Changes and Supplements to Some Laws. Available at: http://www.astu.tuke.sk/ (in Slovak)

[16] Programmeové vyhlásenie vlády Slovenskej republiky z 25 novembra 1998. Úrad vlády Slovenskej republiky. Available at: http://www.vlada.gov.sk (in Slovak)

[17] Slovak Rectors' Conference. 2020. Available at: https://www.srk.sk/en/about-src/general-information

[18] Sprievodca bolonským procesom. Slovenské vysoké školy a bolonský proces. SAAIC-NK Socrates, Bratislava, 2006. (in Slovak)

[19] The Bologna Declaration of 19 June 1999: Joint declaration of the European Ministers of Education. Available at: https://www.eurashe.eu/library/bologna_1999_bologna-declaration-pdf

[20] The Slovak Republic Bologna National Report. 2005. Available at: http://ehea.info/Upload/document/members/slovak_republic/National_Report_Slovak_Republic_2003_ 576426.pdf

[21] Vlčková V. Vývoj a rozmiestnenie vysokých škôl na Slovensku - odraz v regionálnej štruktúre vzdelania ekonomicko aktívneho obyvatel'stva. Bořetice, KVS a RR EU-NHF, 16.-18.6.2010. (in Slovak)

[22] Vyhláška Ministerstva školstva Slovenskej republiky z 27. septembra 2002 o kreditovom systéme štúdia. Zbierka zákonov Slovenskej republiky, č. 614/2002 Z.z., 239, 6250-6264. Available at: https://www.slov-lex.sk/pravne-predpisy/SK/ZZ/2002/614/ (in Slovak)

[23] Vlčková V., Kouřilová J. Vývoj vysokého školství na území České a Slovenské republiky. Czech regional studies, 2 (2010), 34-45. (in Czech)

[24] Uznesenie vlády SR 685/2000 z 30. augusta 2000 k návrhu koncepcie d’alšieho rozvoja vysokého školstva na Slovensku pre 21. Storočie. Available at: http://www.vlada.gov.sk (in Slovak)

[25] Zákon č. 131/2002 Z.z. z 21. februára 2002 o vysokých školách a o zmene a doplnení niektorých zákonov. 2002. Zbierka zákonov SR, Čiastka 58, 1462-1514. (in Slovak)

[26] Zákon č. 131/2002 Z.z. z 21. februára 2002 o vysokých školách a o zmene a doplnení niektorých zákonov. 2002. Zbierka zákonov SR, Čiastka 58, 1508-1510. (in Slovak) 
[27] Zákon č. 131/2002 Z.z. z 21. februára 2002 o vysokých školách a o zmene a doplnení niektorých zákonov. 2002. Zbierka zákonov SR, Čiastka 58, 1483-1486. (in Slovak)

[28] Zakon zo 1989 o vysokych skolach. Zbierka zakonov. Available at: http://www.zbierka.sk (in Slovak)

Address: Iryna Myhovych, State Institution Luhansk Taras Shevchenko National University, 1, Gogol Square, Starobilsk, 92703, Ukraine.

E-mail: irina.migovich@gmail.com

Received: 15.01.2020; revised: 26.02.2020.

Мигович Ірина. Сдовацька система вищої освіти у взаємозв'язку з суспільними трансформаціями: огляд від часів середньовіччя до періоду європейської інтеграції XXI століття. Журнал Прикарпатського університету імені Василя Стефаника, 7 (1) (2020), 134-143.

Стаття представляе спробу дослідити розвиток національної системи вищої освіти Словацької Республіки (як частини колишньої Чехословаччини), починаючи 3 перших відомих даних середньовіччя і до початку XXI століття, коли настає період інтенсивної європеїзації та інтернаціоналізації. Значна увага приділяеться розвитку вищої освіти в Словацькій Республіці після 1989 року з акцентом на відповідне законодавство, кількість студентів, загальну інституційну структуру. Метою статті є представлення теоретичного огляду розвитку словацької національної системи вищої освіти, що визначається процесами суспільно-політичних перетворень в країні, включаючи інтеграцію до Європейського Союзу та Європейського простору вищої освіти (ЄПВО). Теоретичні положення статті підтверджені відповідними статистичними даними про кількість вищих навчальних закладів та кількість студентів, включаючи кількість тих, хто бере участь у схемах мобільності в межах ЄПВО (статистичні показники враховують гендерну залежність). Увагу також приділено розвитку системи законодавства про вищу освіту країни після так званого розпаду Чехословаччини на Чеську та Словацьку Республіки, що дозволило створити та розвинути приватний сектор національної системи вищої освіти. Дослідження грунтується на всебічному аналізі оригінальних джерел - національної законодавчої бази вищої освіти з відкритим доступом, а також теоретичних та практичних дослідницьких робіт словацьких науковців. Актуальність досліджень визначена подібністю словацької та української національних систем вищої освіти кінця XX століття, що дозволяє констатувати, що врахування словацького контексту $є$ актуальним для нинішньої реформуючої національної системи вищої освіти України.

Кдючові слова: Чехословаччина, Словацька Республіка, система вищої освіти, освітня політика, Закон про вищу освіту, європеїзація, інтернаціоналізація, приватний сектор вищої освіти. 